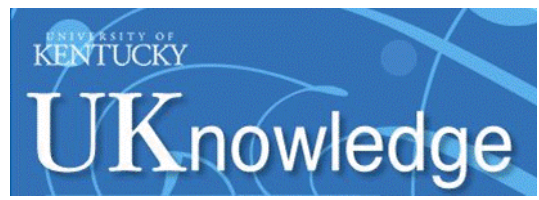

University of Kentucky

UKnowledge

Biosystems and Agricultural Engineering Faculty Publications

Biosystems and Agricultural Engineering

9-2014

\title{
Effect of Soil Sampling Density and Landscape Features on Soil Test Phosphorus
}

\author{
Donald J. Stamper \\ University of Kentucky, donniejstamper@uky.edu \\ Carmen T. Agouridis \\ University of Kentucky, carmen.agouridis@uky.edu \\ Dwayne R. Edwards \\ University of Kentucky, dwayne.edwards@uky.edu \\ Mark A. Purschwitz \\ University of Kentucky, purschwitz@uky.edu
}

Follow this and additional works at: https://uknowledge.uky.edu/bae_facpub

Part of the Bioresource and Agricultural Engineering Commons

Right click to open a feedback form in a new tab to let us know how this document benefits you.

\section{Repository Citation}

Stamper, Donald J.; Agouridis, Carmen T.; Edwards, Dwayne R.; and Purschwitz, Mark A., "Effect of Soil Sampling Density and Landscape Features on Soil Test Phosphorus" (2014). Biosystems and Agricultural Engineering Faculty Publications. 7.

https://uknowledge.uky.edu/bae_facpub/7

This Article is brought to you for free and open access by the Biosystems and Agricultural Engineering at UKnowledge. It has been accepted for inclusion in Biosystems and Agricultural Engineering Faculty Publications by an authorized administrator of UKnowledge. For more information, please contact UKnowledge@lsv.uky.edu. 


\section{Effect of Soil Sampling Density and Landscape Features on Soil Test Phosphorus \\ Digital Object Identifier (DOI) \\ http://dx.doi.org/10.13031/aea.30.10328}

\section{Notes/Citation Information}

Published in Applied Engineering in Agriculture, v. 30, no. 5, p. 773-781.

(c) 2014 American Society of Agricultural and Biological Engineers

The copyright holders have granted the permission for posting the article here. 


\title{
EFFECT OF SOIL SAMPLING DENSITY AND LANDSCAPE FEATURES ON SOIL TEST PHOSPHORUS
}

\author{
D. J. Stamper, C. T. Agouridis, D. R. Edwards, M. A. Purschwitz
}

\begin{abstract}
Organic and/or inorganic fertilizers are used to promote crop growth yet the rate of fertilizer application is often based on the nitrogen needs of the crop and not the phosphorus needs, especially when utilizing animal manures with low N-to-P ratios as compared to plant N:P uptake. Because of this, soil phosphorus levels in many areas of the world are in excess of crop needs. Excessive levels of phosphorus in water bodies such as streams and lakes can result in a condition known as eutrophication. With eutrophication, nutrients promote algal growth which in turn decreases dissolved oxygen levels in receiving water bodies. The issue of excessive nutrient inputs to waterbodies is of particular importance to Kentucky due to its large agricultural base and the Commonwealth's link to hypoxia in the Gulf of Mexico. Nutrient management is one way to minimize the impacts of phosphorus on waterways; however, the success of nutrient management is dependent in part on soil sampling strategies. This study examined the effect of soil sampling density $(15 \times$ $15 \mathrm{~m}, 15 \times 30 \mathrm{~m}$, and $15 \times 60 \mathrm{~m}$ ) on Soil Test Phosphorus (STP) in three subplots. Results indicated that mean STP values for the subplots did not change with sampling densities; however, maximum STP levels displayed large variations. Depending on the sampling density used and the method of data aggregation (mean vs. maximum), recommended nutrient application rates varied from phosphorus-based to nitrogen-based. Also of importance was the recognition that maximum STP values were driven by a shallow limestone rock layer, which was not visible at the time of sampling. This limestone rock layer, and hence these highest STP values, were immediately upgradient of a sinkhole from which collected soil samples also exhibited higher STP values. When developing nutrient management plans, particularly in karst landscapes where the potential for groundwater contamination and hence surface water contamination is higher, additional consideration should be given to the influence of geologic materials on soil nutrient levels and greater sampling densities around preferential flow paths.
\end{abstract}

Keywords. Geology, Nutrient management, Soil sampling, Soil test phosphorus, Water quality.

$\mathrm{P}$ hosphorus $(\mathrm{P})$ is an essential nutrient to plant growth and development, but when high concentrations are present in the soil, such as when levels exceed plant requirements, phosphorus may become a water quality contaminant. Phosphorus in surface runoff can lead to accelerated eutrophication of surface waterbodies such as streams and lakes (Pote et al., 1996). Sims et al. (2000) noted that in many areas of the world, soil concentrations of $\mathrm{P}$ are excessive relative to crop $\mathrm{P}$ requirements. This means that much of the $\mathrm{P}$ applied to crops is not utilized but rather may be available for transport to waterways. Overabundant $\mathrm{P}$ levels in water bodies can promote eutrophication whereby algal growth and decay is promoted to the point that the waters become oxygen depleted (Sharpley et al., 2003). While a number of factors, such as carbon enrichment

Submitted for review in July 2013 as manuscript number SW 10328; approved for publication by the Soil \& Water Division of ASABE in June 2014.

The authors are Donald J. Stamper, Engineer Associate, Carmen T. Agouridis, ASABE Member, Associate Professor, Dwayne R. Edwards, ASABE Member, Professor, and Mark A. Purschwitz, ASABE Member, Extension Professor, Department of Biosystems and Agricultural Engineering, University of Kentucky, Lexington, Kentucky. Corresponding author: Carmen T. Agouridis, 128 C.E. Barnhart Building, Lexington, KY 40546-0276; phone: 859-257-3000 ext. 207; e-mail: carmen.agouridis@uky.edu. (biochemical oxygen demand loading), nitrogen enrichment, canopy cover (light), and season, are linked to eutrophication (Correll, 1998; Dodd, 2006), P has been identified as the most common cause of eutrophication in freshwater bodies (Correll, 1998). Sharpley et al. (2003) noted that in the United States eutrophication is one of the leading water quality impairments. Excess $P$ levels in Kentucky may contribute to the hypoxic or "dead zone" in the Gulf of Mexico. Alexander et al. (2008) utilized the SPARROW model to estimate that $14 \%$ of the P entering the Gulf of Mexico via the Mississippi and Atchafalaya River Basins (MARB) originated from animal manures with streams draining pasture or range lands serving as the primary transport pathway for this excessive P. Based on the large-scale regional water quality model, SPARROW, the authors estimated that Kentucky is one of nine states, including Arkansas, Illinois, Indiana, Iowa, Mississippi, Missouri, Ohio, and Tennessee, that contribute $69 \%$ of the $\mathrm{P}$ delivered $(\sim 10 \%$ of the total $\mathrm{P}$ delivered $)$ from pasture and range lands to the Gulf of Mexico. In addition to pasture and range lands, other significant sources of $P$ include urban areas and crops. Managing P exports from Kentucky's agricultural lands is particularly challenging due to the Commonwealth's large number of streams, karst geology (i.e., strong surface and groundwater connections), and high-P geology and soils (Creesman, 1973). In fields 
underlain with karst geology and/or adjacent to streams, pollutants in runoff can more easily enter surface and/or ground waters (Kaçaroğlu, 1999; Currens, 2002; Hansen et al., 2002). As noted by Veni (2002), Kentucky is not alone in these challenges as the other eight states that are significant Gulf $\mathrm{P}$ contributors also have significant regions of karst geology.

Precision nutrient management is a farm management tool that may aid in the protection of natural resources. Precision management requires detailed spatial resolution knowledge of soils and soil variability (McBratney and Pringle, 1999). As such, soil testing is generally performed to determine current nutrient concentrations prior to nutrient addition (Sharpley et al., 2001; Bolster, 2011; UKCES, 2012; Higgins et al., 2014). Soils rich in P, whether naturally or from over-application of manures, pose challenges for producers trying to determine Soil Test Phosphorus (STP) levels for their fields and thus the proper amount of nutrients to apply. In Kentucky, provided that an operation does not require a comprehensive nutrient management plan per its participation in a federal program, the amount of phosphorus that can be applied to crops is based on STP levels outlined in the Kentucky Nutrient Management Plan (Higgins et al., 2014) per authority of the Kentucky Agricultural Water Quality Act (table 1). However, if an operation is participating in a federal program and a comprehensive nutrient management plan is required, KY NRCS Code 590 (NRCS, 2013), which was developed in conjunction with the Kentucky Division of Water, is used. The NRCS conservation practice standard (Code 590) uses the STP thresholds presented in Higgins et al. (2014) in addition to other factors such as soil type (soil mapping unit), field slopes, and application method to compute a Phosphorus Index which aids in determining $\mathrm{P}$ application rates (NRCS, 2013). The STP thresholds, shown in table 1, are not based on a defined number of soils samples per hectare or per field or a statistical parameter such as the field mean, median or maximum. Instead, the producer must decide where to collect soil samples, how many to collect, and how to analyze the data. The only requirement specified is that soil testing occurs within one-year of manure application (Higgins et al., 2014). With the Kentucky Nutrient Management Plan (Higgins et al., 2014), once STP levels exceed $448 \mathrm{~kg} \mathrm{ha}^{-1}$, allowable manure application rates are based on $\mathrm{P}$ levels rather than nitrogen levels, which can pose a challenge to producers. As crops require less $\mathrm{P}$ than nitrogen (Eghball and Power, 1999), less manure can be land applied, meaning the producer must identify an alternate means of manure disposal (Bremer et al., 2008; Olson et al., 2010).

One of the most critical aspects determining STP levels is obtaining representative soil samples (Adamchuk et al.,

Table 1. Kentucky nutrient management plan standards for phosphorus based manure application.

\begin{tabular}{cl}
\hline $\begin{array}{c}\text { Soil Test Phosphorus (STP) } \\
\text { Levels }\left(\mathrm{kg} \mathrm{ha}^{-1}\right)\end{array}$ & Recommended Manure Application Rate \\
\hline$<448$ & Crop nitrogen requirements \\
$449-672$ & Crop phosphorus requirements \\
$673-896$ & Half of crop phosphorus requirements \\
$\geq 897$ & No phosphorus application allowed \\
\hline
\end{tabular}

2004) as P levels can be quite variable throughout a field (Frazen and Peck, 1995). Soil samples can be collected based on areas, zig zag patterns, or grid patterns and then composited or analyzed individually (Thom et al., 2003). For precision agricultural applications, Robert (2002) indicated that grid sampling is common. Grid sampling involves sampling in a regular pattern, usually square or rectangular. Grid density is dependent on a number of factors such as the uniformity of the field with respect to factors such as soil mapping type and past management as well as anticipated economic benefit (Franzen and Peck, 1995; Thom et al., 2003). Mallarino and Wittry (1997) recommended the use of grid sizes of 0.8 ha $(90 \times 90 \mathrm{~m})$ or less. Wollenhaupt et al. (1994) suggested the use of smaller grid sizes on the order of 0.36 ha $(60 \times 60 \mathrm{~m})$ or less. Many sampling recommendations, though, are more general. In the 1920s, Lindsey and Bauer (1929) recommended 1.4 samples per ha, but by the $1940 \mathrm{~s}$, that recommendation had decreased to 0.68 samples per ha. Thom et al. (2003) recommended one sample per ha even while acknowledging that a single hectare grid can have as much variability as an entire field. Variations also exist with regards to the methods of compositing soil samples. Mallarino and Wittry (2004) collected about 20 soil core samples from an $80 \mathrm{~m}^{2}$ field to form a composite. Franzen and Peck (1995) used five soil core samples to create one composite sample for a $25.1 \mathrm{~m}$ grid. One core was taken at the center of the grid while the remaining four were collected at a $4.9 \mathrm{~m}$ radius from the center of the grid. Thom et al. (2003) recommend taking 10 random soil core samples in a 1 ha grid to create one composite.

Lacking is many sampling strategies are the emphasis on sampling based on landscape features. For example, the guidelines presented in Thom et al. (2003), though developed in Kentucky which is a state with extensive karst geology, do not specify the collection of soil samples based on landscape features such as rock outcrops, which might result in higher STP levels, through the weathering of phosphatic rock (Cressman, 1973). Sinkholes are another landscape feature, common to karst landscapes, which may influence STP levels in the soil. Sinkholes are formed by the dissolution of soluble rock, such as limestone (White et al., 1970), and the subsequent erosion of soil into the subsurface layer (Zhou and Beck, 2008). The dissolution and erosion processes result in surface depressions, which for solution sinkholes can vary in size from tens to hundreds of (Beck, 2004). As P transport is associated with runoff, erosion, and macropore flow (Pote et al., 1999; Hansen et al., 2002; Fuchs et al., 2009), it is quite possible that water flowing into sinkholes will result in greater levels of STP at the bottom of sinkholes as compared to the top. Alloush et al. (2003) noted higher concentrations of $\mathrm{P}$ at the bottom of sinkholes as compared to the rims suggesting that landscape position is an important factor in STP levels.

Furthermore, in most real-world soil sampling scenarios, a balance must be struck between the precision of the data collected and the cost of collection and analysis. Collecting too few samples can indicate that higher or, conversely, 
lower nutrient application rates are agronomically acceptable resulting in either increased nutrient levels in runoff or poorer crop yields, respectively. At the University of Kentucky's Regulatory Services (UKRS) lab, a routine STP analysis costs $\$ 5$ per sample. While a single soil sample is not cost prohibitive, for the field-scale where multiple soil samples are needed, costs can be an issue. In such situations, determining the optimum number of soil samples becomes an important issue. It is also important, when developing a sampling strategy, to consider collecting soil samples specifically from landscape features that may cause increases in STP levels in soils, such as rock outcrops, or those that may have soils with increased STP levels due to their location in the landscape, such as sinkholes. For sinkholes, elevated STP levels may be of greater concern due to their strong surface and ground water connections. The objective of this study was to evaluate the effect of grid-sampling density and landscape features on STP levels and hence manure application rate recommendations.

\section{MeTHODS}

A portion of a cornfield at the University of Kentucky's Oran C. Little Research Center, which is located in Woodford County, Kentucky (38 $5^{\circ} 15.07 " \mathrm{~N}$, $\left.84^{\circ} 44^{\prime} 27.76^{\prime \prime} \mathrm{W}\right)$, was used to create three adjacent, rectangular subplots (A, B, and $\mathrm{C})$. The three rectangular subplots were created because, at the Research Center, it was not possible to create one larger, rectangular-shaped homogeneous plot that contained a sinkhole. A rectangular plot configuration was desired to better allow for the examination of multiple grid sizes. The subplots all had the same Maury silt loam soil mapping unit, similar slopes, and were managed in a similar manner (e.g., cropping practices and fertilization rates). The average slope for subplot A was $4.6 \% ; 4.2 \%$ for subplot B; and 3.7\% for subplot C. Subplot dimensions differed slightly in order to maintain a more constant slope within each subplot. Subplots A, B, and C had dimensions of $75 \times 120 \mathrm{~m}, 45 \times 75 \mathrm{~m}$, and $45 \times 75 \mathrm{~m}$, respectively. These dimensions were based on a $15 \times 15 \mathrm{~m}$ grid soil sampling pattern (Cambardella and Karlen, 1999), the smallest grid size to be tested. A sinkhole was located in subplot A but not in subplots B and C. A limestone rock outcrop was discovered, largely in subplot B, after the field was plowed several months following the soil sampling (fig. 1). At the time of sampling, the rock was not visible but rather was buried beneath about $15 \mathrm{~cm}$ of soil. During the planting of winter wheat, a portion of the limestone was broken and plowed to the surface where it was visible on a subsequent field visit.

The locations of the subplots were predetermined in the office using ArcGIS. A Garmin Oregon 550t hand-held GPS (Garmin International, Inc., Olathe, Kans.) was used to locate each corner of the subplots. To complete the grids, measuring tapes were stretched from each corner point, and flags were placed every $15 \mathrm{~m}$ in between the corner points to create subplot borders. Once the borders were completed, a measuring tape was stretched from border to

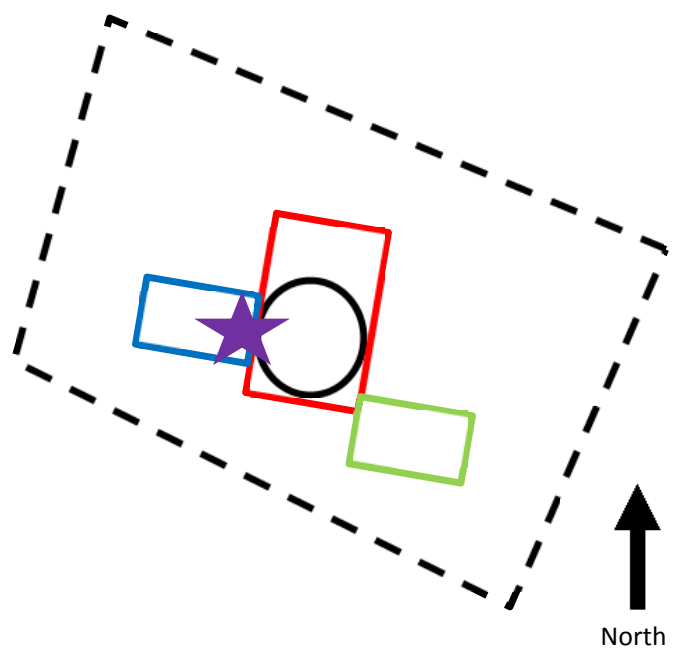

Figure 1. Location map for subplots A (red), B (blue), and C (green). The field border is denoted by the dashed black line, the sinkhole by the solid black line, and the limestone rock outcrop by the purple star. Sizes are relative.

border across the individual plots, and additional flags were placed every $15 \mathrm{~m}$ to complete the $15 \times 15 \mathrm{~m}$ grid.

Based on recommendations found in Thom et al. (2003), sample cores were taken to a depth of $10 \mathrm{~cm}$ using a sampling probe with a $22 \mathrm{~mm}$ ID. One core sample was taken at each grid point resulting in $15 \times 15 \mathrm{~m}$ grid spacing. Fifty-four samples were collected from subplot A (60 samples per ha) and 24 samples each from subplots B and C (71 samples per ha). Since a15 $\mathrm{m}$ uniform grid spacing was used, variable grid densities could be created by removing points (samples) from the $15 \times 15 \mathrm{~m}$ grid. For all three subplots, points were removed up and down the slope with respect to the sinkhole (fig. 2). Two lower density grids were also examined, a $15 \times 30 \mathrm{~m}$ and $15 \times$ $60 \mathrm{~m}$ grids (Franzen et al., 1998). This technique was also performed by Mallarino and Wittry (2004) who used the grid spacing with the highest density as a base to compare less dense (coarser) grids. At the $15 \times 30$ grid spacing, subplot A had 30 samples and subplots B and $C$ each had 12 samples. At the $15 \times 60 \mathrm{~m}$ grid spacing, subplot $\mathrm{A}$ had 18 samples while subplots $B$ and $C$ each had 8 samples.

Soil cores were placed in coolers and transported to the UKRS for analysis. Samples were analyzed for STP (Mehlich III) (Soil and Plant Analysis Council, 2000). Following sample collection, the location and elevation of each core sample were identified using a Trimble SPS930 Universal Total Station (Trimble, Dayton, Ohio) which has a horizontal accuracy of $3 \mathrm{~mm}$ at $100 \mathrm{~m}(7 \mathrm{~mm}$ at $500 \mathrm{~m})$ and a vertical accuracy of $1 \mathrm{~mm}$ at $100 \mathrm{~m}(5 \mathrm{~mm}$ at $500 \mathrm{~m})$. Using the $15 \times 15 \mathrm{~m}$ grid as a base for comparison, contour maps were created using the kriging method in Surfer 11 (Golden Software, Inc., Golden, Colo.). The effect of grid size on STP levels was evaluated using one-way Analysis of Variance tests (ANOVAs) $(\alpha=0.05)$ in SigmaPlot 12 (Systat Software Inc., San Jose, Calif.). Natural log transformations were used to normalize the data. 


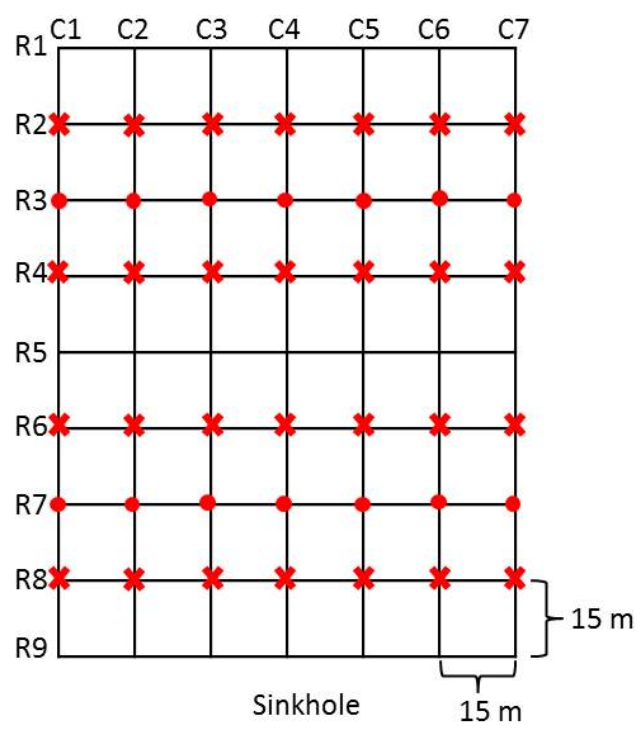

(a)

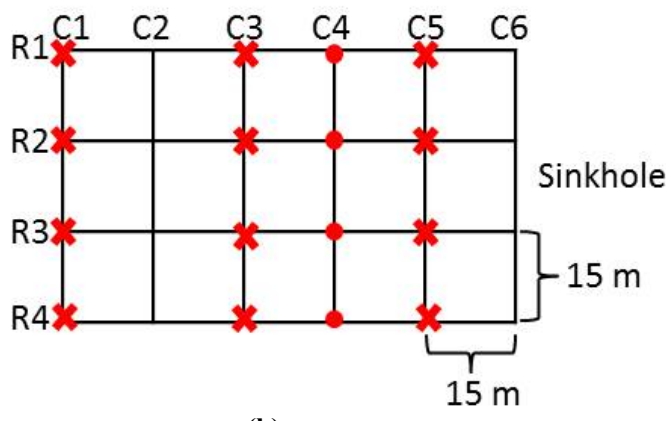

(b)

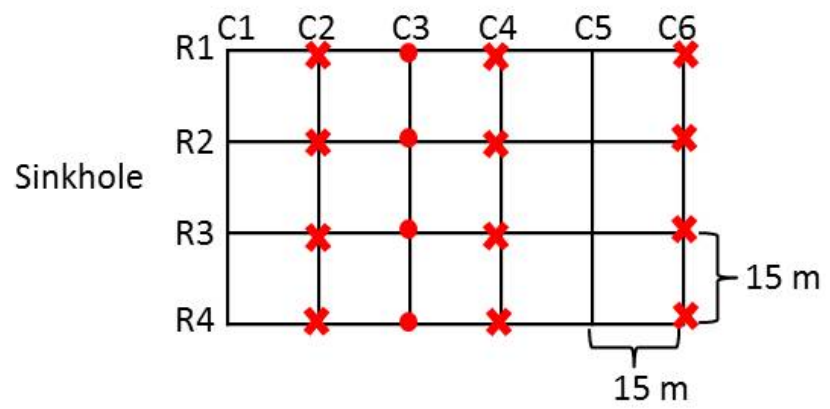

(c)

Figure 2. Soil sample core locations for subplots A (a), B (b), and C (c). In the $15 \times 15 \mathrm{~m}$ density grids, samples were collected at all row (R) and column (C) intersections. Sample points denoted by red Xs were removed to make the $15 \times 30 \mathrm{~m}$ grids. Sample points denoted by red Xs or red circles were removed to make the $15 \times 60 \mathrm{~m}$ grids.

\section{RESULTS AND DISCUSSION GRID SIZE}

Table 2 contains the ranges, medians, and coefficients of variation, all untransformed values, for each subplot at the three examined grid sizes. As the grid size increased to $15 \times$ $30 \mathrm{~m}$ and $15 \times 60 \mathrm{~m}$, the range and maximum values tended to decrease among the subplots; however, variability in the data was high. Results of one-way ANOVAs indicated no significant differences in STP between the grid sizes $(15 \times$ $15 \mathrm{~m}$ vs. $15 \times 30 \mathrm{~m}$ vs. $15 \times 60 \mathrm{~m}$ ) for each subplot.

As noted previously, a threshold STP level of $448 \mathrm{~kg} \mathrm{ha}^{-1}$ triggers P-based manure application planning (Higgins et al., 2014). However, specifications are not provided regarding the number of samples required nor the statistical parameter(s) to use when developing a manure application plan. While median STP levels were well below the threshold value for P-based manure application (table 2), the maximum $P$ values of 641 and $996 \mathrm{~kg} \mathrm{ha}^{-1}$ for subplots A and $\mathrm{B}$, respectively, $(15 \times 15 \mathrm{~m}$ grid $)$ and $604 \mathrm{~kg} \mathrm{ha}^{-1}$ for subplot B $(15 \times 30 \mathrm{~m}$ grid $)$ exceeded it. For subplot A $(15 \times$ $15 \mathrm{~m}$ grid), only one sample (2\%) was greater than $448 \mathrm{~kg}$ $\mathrm{ha}^{-1}$, and this sample was collected from the limestone rock outcrop area (fig. 3a). In the case of subplot B $(15 \times 15 \mathrm{~m})$, three samples (13\%) were greater than $448 \mathrm{~kg} \mathrm{ha}^{-1}$, and these samples were collected at the location of the limestone rock outcrop that was immediately up-gradient of the sinkhole. At the $15 \times 30 \mathrm{~m}$ grid spacing for subplot $\mathrm{B}$, only one sample $(8 \%)$ was greater than $448 \mathrm{~kg} \mathrm{ha}^{-1}$, and it too was from the location of the limestone rock outcrop. If maximum STP levels are used as the evaluation criterion, then for subplots A $(15 \times 15 \mathrm{~m})$ and $\mathrm{B}(15 \times 30 \mathrm{~m})$, the $\mathrm{P}$ application rate should not exceed the estimated removal of $\mathrm{P}$ in the harvested biomass. For subplot B $(15 \times 15 \mathrm{~m})$, the maximum STP value indicates that the $\mathrm{P}$ application rate should undergo further restriction to no more than one half of the estimated $P$ removal rate of the harvested biomass.

Commonly, decisions on how to manage $\mathrm{P}$ are based upon mean STP values for a field, regardless of the amount of variability present in the data (Stephen Higgins, University of Kentucky, personal communication, 30 January 2014). The STP means for all subplots at all grid sizes are at a level where application rates based on nitrogen are recommended (table 3 ). By not considering the variability in the data, and in particular the specific locations in a field where the maximum values occur, it is possible that the higher applications rates in these localized areas could mean a greater chance for excess $\mathrm{P}$ to enter waterways. In this study, the higher $\mathrm{P}$ rates were found at the location of the limestone rock outcrop, which was immediately up-gradient of the sinkhole, and in sinkhole itself (figs. 3-4). Accumulation of $\mathrm{P}$ in the sinkhole is of concern as this karst feature can provide a quick conduit for runoff, and the constituents in runoff, to enter ground waters (Kaçaroğlu, 1999; Currens, 2002; Hansen et al., 2002). Miller et al. (2011) found that P-based manure application rates resulted in $50 \%$ to $94 \%$ lower levels of dissolved $\mathrm{P}$ in runoff as compared to nitrogen-based application rates. Also, research has shown that STP is

Table 2. Range, mean, and Coefficient of Variation (CV) for soil test phosphorus ( $\left.\mathrm{kg} \mathrm{ha}^{-1}\right)$ for each grid size.

\begin{tabular}{|c|c|c|c|c|c|c|c|c|c|}
\hline \multirow[b]{2}{*}{ Grid Size } & \multicolumn{3}{|c|}{ Subplot A } & \multicolumn{3}{|c|}{ Subplot B } & \multicolumn{3}{|c|}{ Subplot C } \\
\hline & $\mathrm{n}$ & Range & Median (CV) & $\mathrm{n}$ & Range & Median (CV) & $\mathrm{n}$ & Range & Median $(\mathrm{CV})$ \\
\hline $15 \times 15 \mathrm{~m}$ & 54 & $46-641$ & $139(57 \%)$ & 24 & $71-996$ & $189(79 \%)$ & 24 & $28-268$ & $100(53 \%)$ \\
\hline $15 \times 30 \mathrm{~m}$ & 30 & $46-332$ & $136(41 \%)$ & 12 & $102-604$ & $197(60 \%)$ & 12 & $52-268$ & $112(53 \%)$ \\
\hline $15 \times 60 \mathrm{~m}$ & 18 & $46-332$ & $134(50 \%)$ & 8 & $71-361$ & $208(48 \%)$ & 8 & $66-268$ & $104(57 \%)$ \\
\hline
\end{tabular}




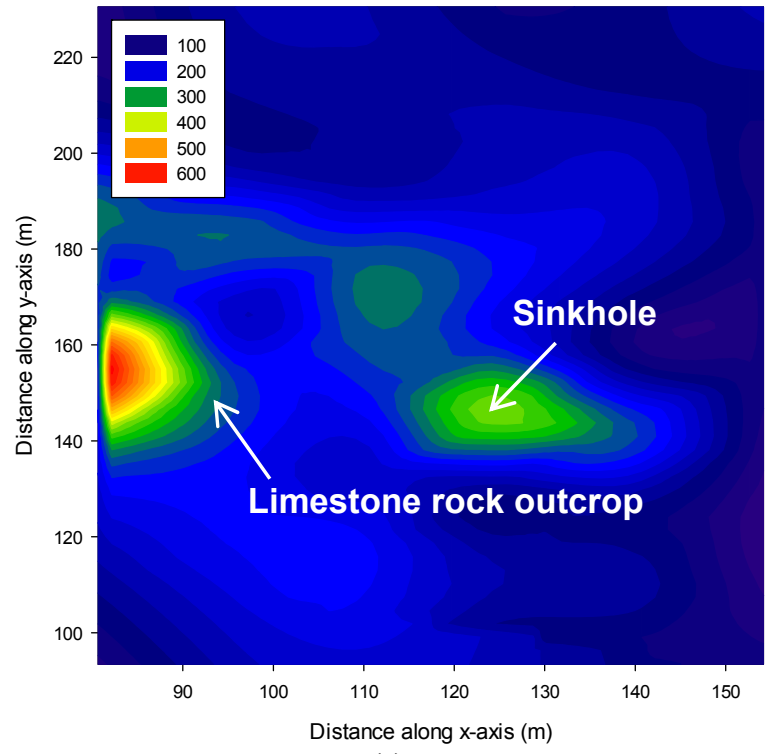

(a)



(b)



(c)

Figure 3. Soil Test Phosphorus (STP) levels $\left(\mathrm{kg} \mathrm{ha}^{-1}\right)$ in subplot $A$ for the (a) $15 \times 15 \mathrm{~m}$ grid, (b) $15 \times 30 \mathrm{~m}$ grid, and (c) $15 \times 60 \mathrm{~m}$ grid.

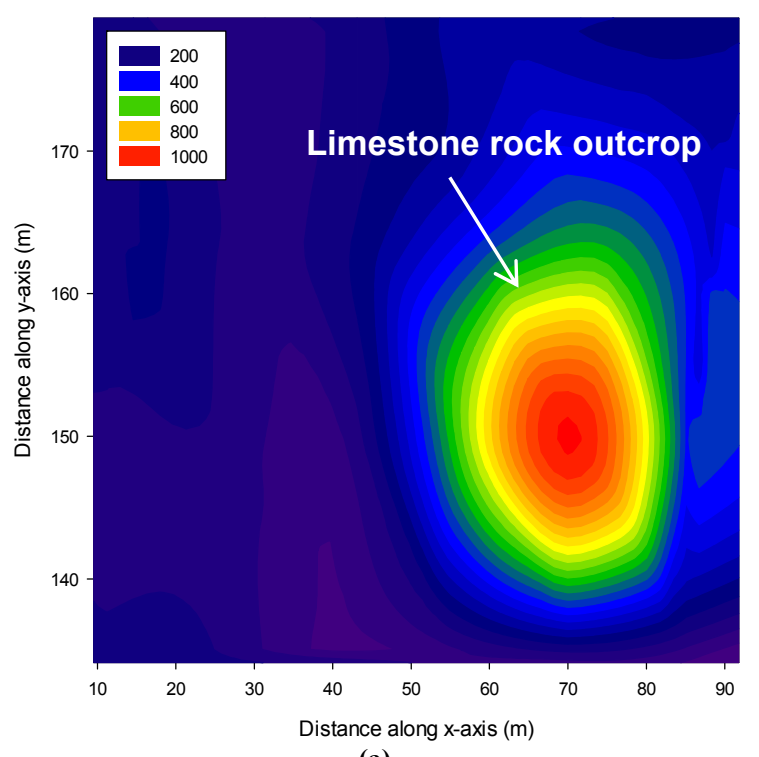

(a)

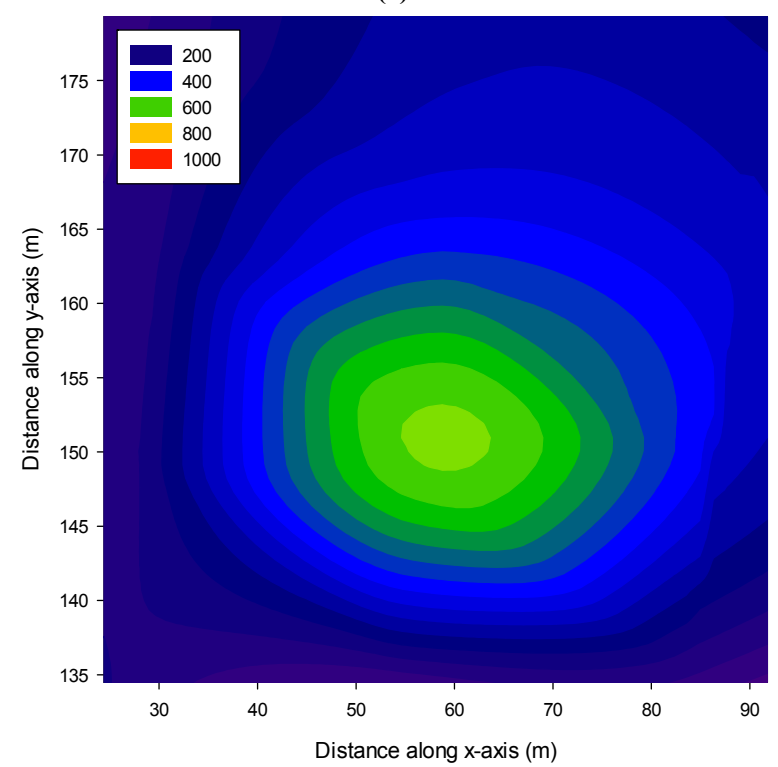

(b)

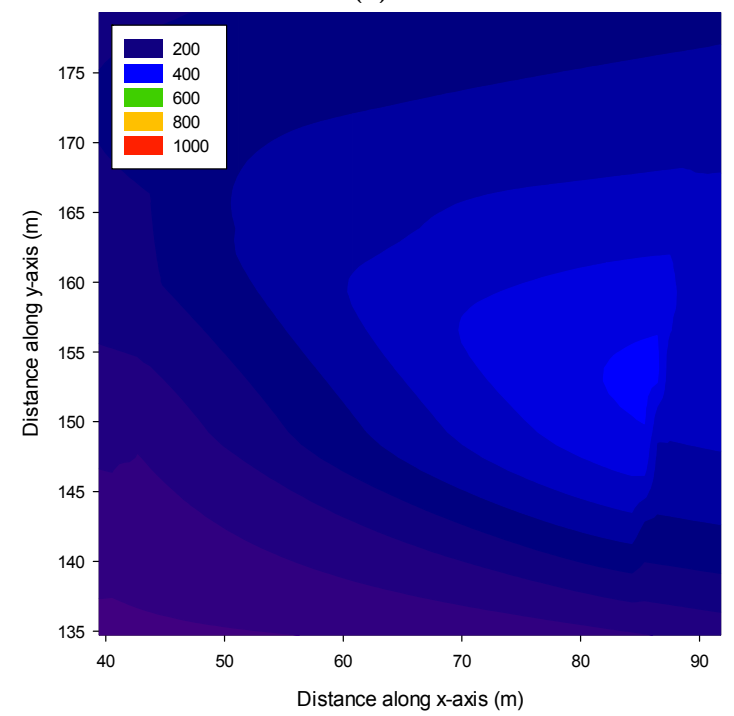

(c)

Figure 4. Soil Test Phosphorus (STP) levels $\left(\mathrm{kg} \mathrm{ha}^{-1}\right)$ in subplot $B$ for the (a) $15 \times 15 \mathrm{~m}$ grid, (b) $15 \times 30 \mathrm{~m}$ grid, and (c) $15 \times 60 \mathrm{~m}$ grid. 
significantly correlated with dissolved reactive $\mathrm{P}$ in runoff (Pote et al., 1996). Thus, it is important to protect sinkholes. As noted by Higgins et al. (2014), Kentucky specifies setbacks for producers required to obtain a Kentucky No Discharge Operating Permit (KNDOP). Such producers are those with a liquid manure handling system and/or those who land apply manure. For land application, the setback distance depends on the method of land application, but is a minimum of $23 \mathrm{~m}$ from blue-line streams and karst features when the method of application is injection. At the study site, where the method of manure application was injection, a setback distance of $23 \mathrm{~m}$ may not be sufficient as transported $\mathrm{P}$ from up-gradient areas has accumulated in the sinkhole (fig. 3). To reduce $\mathrm{P}$ accumulation at this site, it may be necessary to increase the setback distance and/or reduce the rate of manure application on lands up-gradient of the sinkhole.

\section{GEOLOGIC INFLUENCE}

The wide range of STP values measured in the subplots, particularly $\mathrm{A}$ and $\mathrm{B}$, point to the degree of variability that can be present even in small areas as seen in figures 3-5. The cause of this variability is unknown, but is it hypothesized that it may be related to the presence of the limestone rock outcrop in subplots $\mathrm{A}$ and $\mathrm{B}$ and the sinkhole in subplot $\mathrm{A}$. The location of the limestone rock outcrop, in subplots A and B, drains to the sinkhole in subplot $\mathrm{A}$. The limestone rock underlying the sampled area is known as Lexington Limestone (Cressman, 1973). This portion of the Lexington Limestone contains the Devils Hollow Member which is a known phosphatic limestone. Surface exposures of this member are common in this portion of central Kentucky. Cressman (1973) noted that these surface limestone rock exposures tend to weather rapidly, which may account for some of the localized elevated STP levels seen in subplots A and B. Thomas et al. (1992) noted that P levels were higher in Kentucky streams flowing over phosphatic limestone. A portion of subplot C had higher STP levels; however, no limestone rocks or depressions were identified in this subplot. Hence, the reason for this area of higher STP values is not known.

Sinkholes, which are byproducts of karst topography, can act as conduits for above-ground pollutants to reach the groundwater (Kaçaroğlu, 1999; Currens, 2002; Coxon, 2011). Coxon (2011) noted that groundwater contamination in karst landscapes is not limited to readily mobile constituents such as nitrate but also includes $\mathrm{P}$, fecal bacteria, and pesticides. Fissures and other such features in easily dissolved carbonate rock provide a network of pathways for surface contaminants to enter the groundwater. Studies have shown that in karst landscapes, groundwater can provide a pathway for $\mathrm{P}$ to enter surface waters (Grant et al., 1996; Kilroy et al., 2001; McCobb et al., 2003; Polyakov, et al., 2005; Fuchs et al., 2009; Mittelstet et al., 2011). And while Kentucky has setback standards for land application of manure in proximity to karst features, as seen in this study, the setback distance may not be sufficient to prevent higher STP levels in and near karst features such as sinkholes. Because of their ability to transport pollutants in runoff to ground waters,

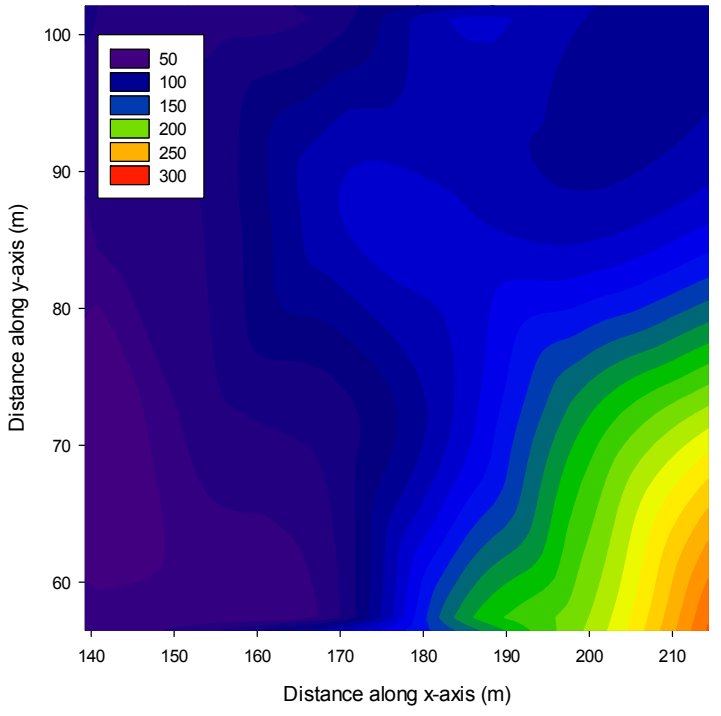

(a)

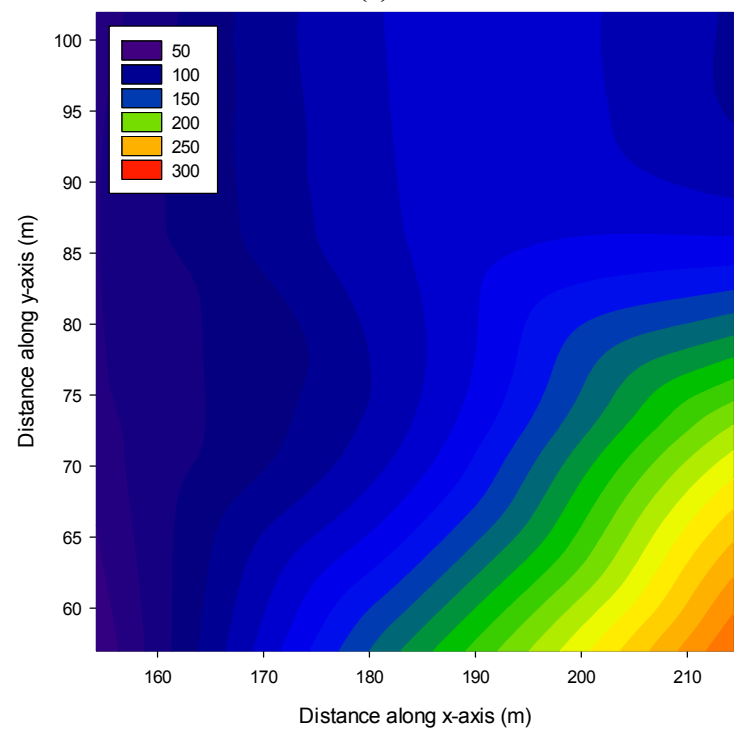

(b)

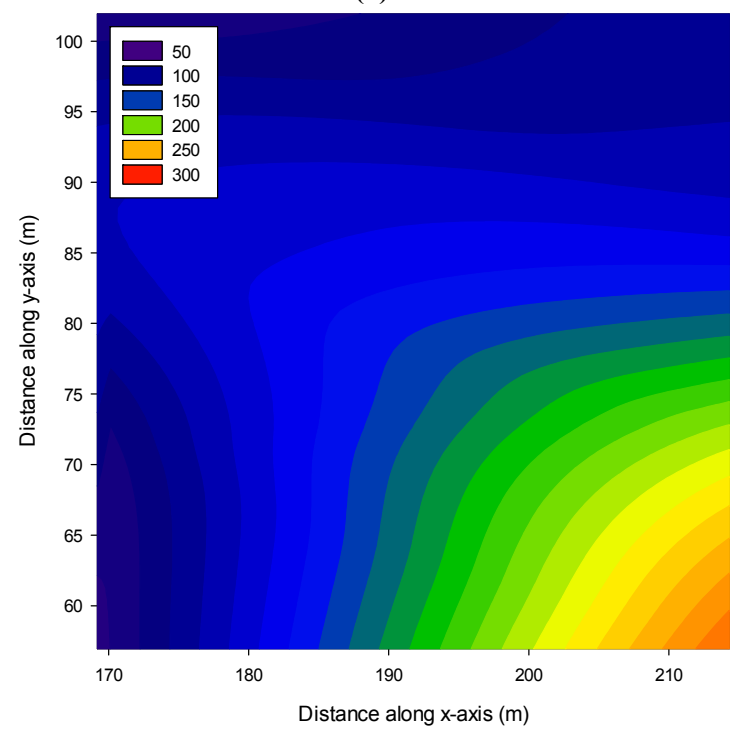

(c)

Figure 5. Soil Test Phosphorus (STP) levels $\left(\mathrm{kg} \mathrm{ha}^{-1}\right)$ in subplot $\mathrm{C}$ for the (a) $15 \times 15 \mathrm{~m}$ grid, (b) $15 \times 30 \mathrm{~m}$ grid, and (c) $15 \times 60 \mathrm{~m}$ grid. 
Table 3. Soil test phosphorus threshold levels and corresponding allowable application rates Kentucky nutrient management guidelines (Higgins et al., 2014).

\begin{tabular}{|c|c|c|c|c|c|}
\hline Grid & Subplot & Mean $\left(\mathrm{kg} \mathrm{ha}^{-1}\right)$ & Application Criterion & $\operatorname{Maximum}\left(\mathrm{kg} \mathrm{ha}^{-1}\right)$ & Application Criterion \\
\hline \multirow{3}{*}{$15 \times 15 \mathrm{~m}$} & $\mathrm{~A}$ & 167 & Nitrogen based & 641 & Phosphorus based \\
\hline & B & 255 & Nitrogen based & 996 & Phosphorus based \\
\hline & $\mathrm{C}$ & 106 & Nitrogen based & 268 & Nitrogen based \\
\hline \multirow{3}{*}{$15 \times 30 \mathrm{~m}$} & $\mathrm{~A}$ & 147 & Nitrogen based & 332 & Nitrogen based \\
\hline & $\mathrm{B}$ & 247 & Nitrogen based & 604 & Phosphorus based \\
\hline & $\mathrm{C}$ & 120 & Nitrogen based & 268 & Nitrogen based \\
\hline \multirow{3}{*}{$15 \times 60 \mathrm{~m}$} & $\mathrm{~A}$ & 160 & Nitrogen based & 332 & Nitrogen based \\
\hline & B & 203 & Nitrogen based & 361 & Nitrogen based \\
\hline & $\mathrm{C}$ & 126 & Nitrogen based & 268 & Nitrogen based \\
\hline
\end{tabular}

sinkholes should receive additional consideration in nutrient management. Of particular importance is when sinkholes are located near other geologic features, such as a phosphatic limestone rock layer. As seen in figure 3, the fact that these limestone rocks are located upgradient of the sinkholes suggests that as the rocks weather, $\mathrm{P}$ is being transported to the sinkhole.

The size of the sampling grid is also important. As seen in figures 3 and 4, when the grid size was increased, the effect of the sinkhole and the limestone rock outcrop, where STP levels were the highest, diminished. In both subplots A and B, the maximum STP levels dropped below the threshold for phosphorus-based applications within one and two grid size increases, respectively. These results suggest that a zone sampling strategy (Franzen et al., 2000), which is based on topography, is warranted in areas with such karst geology. It is anticipated that tighter sampling (e.g., $15 \times 15 \mathrm{~m}$ ) in and along the perimeter of the sinkhole, coupled with a larger sampling grid in the other areas of the field, would also have revealed this small zone of high STP. Such a zone or zone and grid combination sampling strategy may be an appropriate balance between cost and environmental protection.

\section{Conclusions}

Nutrient management is an important best management practice for protecting surface waters, and soil sampling is an integral part of nutrient management. One decision a producer must make is the density at which soil samples are collected. Another is how to best synthesize or aggregate the results to accomplish production and environmental protection needs. The results of this study demonstrate that sampling density or grid size as well as the method of data aggregation can alter nutrient management decisions. For all subplots and all grid sizes, the use of the median or mean values would result in a nitrogen-based application rate. However, if maximum values were considered, then for two of the three plots, the smallest grid size $(15 \times 15 \mathrm{~m})$ would suggest that a P-based application rate is more appropriate. The decision of how to collect and analyze soil samples for determining nutrient application rates should consider the presence of streams and surface to groundwater preferential flow paths, such as sinkholes, particularly in karst landscapes where nutrients applied to the land can reach surface and ground waters quickly. To that effect, tighter grids around environmentally significant landscape features, such as limestone rock outcrops and sinkholes, can help identify localized high STP areas and hence afford these landscape features a greater level of protection through precision application of animal manure fertilizers.

Results from this study also point to the need to examine geological influences at the field-scale. Soils overlaying the shallow limestone rock layer, which was not visible at the time of sampling, were found to have the highest STP levels. Hence, understanding how geologic materials influence STP is of importance in developing a nutrient management strategy. Fields overlaying geologic formations known to have high phosphorus contents may require sampling at a greater density, particularly around preferential flow paths such as sinkholes.

While this study showed that finer sampling grids can precisely delineate environmentally significant but nondominant high STP areas, this precision comes at a price. Finer sampling grids can mean improved resource management around environmentally significant landscape features such as streams and sinkholes, but such sampling grids also mean that the producer must incur greater sample costs (e.g., costs associated with sample collection, preprocessing, and analysis). Tools which allow producers to minimize these costs are needed to encourage environmental stewardship without incurring excessive financial hardships.

\section{ACKNOWLEDGEMENTS}

The authors would like to thank Dr. Michael Sama for his assistance in operating the total station. The authors would also like to thank the three anonymous reviewers for their insightful comments. This project was funded by the University of Kentucky's Department of Biosystems and Agricultural Engineering as well as the U.S. Department of Agriculture, Natural Resource Conservation Service (685C16-10-058). Any opinions, findings, and conclusions or recommendations expressed in this publication are those of the authors and do not necessarily reflect the views of the United States Department of Agriculture, Natural Resource Conservation Service.

\section{REFERENCES}

Adamchuk, V. I., Hummel, J. W., Morgan, M. T., \& Upadhyaya, S. K. (2004). On-the-go soil sensors for precision agriculture. Comput. Electron.Agr., 44, 71-91. doi:http://dx.doi.org/10.1016/j.compag.2004.03.002. 
Alexander, R. B., Smith, R. A., Schwarz, G. E., Boyer, E. W., Nolan, J. V., \& Brakebill, J. W. (2008). Differences in phosphorus and nitrogen delivery to the Gulf of Mexico from the Mississippi River Basin. Sci.Tech., 42, 822-830. doi:http://dx.doi.org/10.1021/es0716103.

Alloush, G. A., Boyer, D. G., Belesky, D. P., \& Halvorson, J. J. (2003). Phosphorus mobility in a karst landscape under pasture grazing system. Agronomie, 23, 593-600. doi:http://dx.doi.org/10.1051/agro:2003328.

Beck, B. F. (2004). Soil piping and sinkhole failures. In D. C. Culver, \& W. B. White (Eds.), Encyclopedia of Caves (pp. 521526). Amsterdam: Elsevier.

Bolster, C. H. (2011). A critical evaluation of the Kentucky phosphorus index. J. Ky. Acad. Sci., 72, 46-58.

Bremer, V. R., Koelsch, R. K., Massey, R. E., \& Erickson, G. E. (2008). Effects of distillers grains and manure management on nutrient management plans and economics. Nebraska Beef Cattle Reports, Paper 26. Retrieved from http://digitalcommons.unl.edu/animalscinbcr/26.

Cambardella C A and Karlen D K (1999) Spatial analysis of soil fertility parameters. Precision Agric. 1, 5-14.

Correll, D. L. (1998). The role of phosphorus in the eutrophication of receiving waters: a review. J. Environ. Qual., 27(2), 261-266. doi:http://dx.doi.org/10.2134/jeq1998.00472425002700020004x.

Coxon, C. (2011). Chapter 5: Agriculture and Karst. In P. E. van Beynen (Ed.), Karst Management (pp. 103-138). New York, N.Y.: Springer.

Cressman, E. R. (1973). Lithostratigraphy and depositional environments of Lexington limestone (ordovician) of central Kentucky. U.S. Geological Survey Professional Paper 768. Retrieved from http://pubs.er.usgs.gov/publication/pp768.

Currens, J. (2002). Kentucky is karst country! What you should know about sinkholes and springs. Information Circular 4, Series XII: Kentucky Geological Survey. Retrieved from http://kgs.uky.edu/kgsweb/olops/pub/kgs/ic04_12.pdf.

Dodd, W. K. (2006). Eutrophication and trophic state in rivers and streams. Limnol. Oceanogr., 51, 671-680. doi:http://dx.doi.org/10.4319/lo.2006.51.1_part_2.0671.

Eghball, B., \& Power, J. F. (1999). Phosphorus- and nitrogen-based manure and compost applications: corn production and soil phosphorus. Soil Sci. Soc. Am. J., 63(4), 895-901. doi:http://dx.doi.org/10.2136/sssaj1999.634895x.

Franzen, D. W., \& Peck, T. R. (1995). Field soil sampling density for variable rate fertilization. J. Prod. Agric., 8(4), 568-574. doi:http://dx.doi.org/10.2134/jpa1995.0568.

Franzen, D. W., Cihacek, L. J., Hofman, V. L., \& Swenson, L. J. (1998). Topography-based sampling compared with grid sampling in the Northern Great Plains. J. Prod. Agric., 11(3), 364-370. doi:http://dx.doi.org/10.2134/jpa1998.0364.

Franzen, D. W., Halvorson, A. D., \& Hoffman, V. L. (2000). Management zones for soil $\mathrm{N}$ and $\mathrm{P}$ levels in the northern Great Plains. In P. C. Robert, R. H. Rust, \& W. E. Larson (Ed.), Proc. of the 5th Intl. Conf. on Precision Agriculture. Bloomington, Minn.: ASA-CSSA-SSSA.

Fuchs, J. W., Fox, G. A., Storm, D. E., Penn, C. J., \& Brown, G. O. (2009). Subsurface transport of phosphorus in riparian floodplains: influence of preferential flow paths. J. Environ. Qual., 38(2), 473-484.

doi:http://dx.doi.org/10.2134/jeq2008.0201.

Grant, R., Laubel., A., Kronvang, B., Andersen, H. E., Svendsen, L. M., \& Fuglsang, A. (1996). Loss of dissolved and particulate phosphorus from arable catchments by subsurface drainage. Wat. Res., 30(11), 2633-2642. doi:http://dx.doi.org/10.1016/S0043-1354(96)00164-9.
Hansen, N. C., Daniel, T. C., Sharpley, A. N., \& Lemunyon, J. L. (2002). The fate and transport of phosphorus in agricultural systems. J. Soil Water Conserv., 57, 408-417.

Higgins, S., Schmidt, K, \& Gumbert, A.. (2014). ID-211 Kentucky nutrient management planning guidelines (KyNMP). University of Kentucky Cooperative Extension Service. http://www2.ca.uky.edu/agc/pubs/ID/ID211/ID211.pdf .

Kaçaroğlu, F. (1999). Review of groundwater pollution and protection in karst areas. Water Air Soil Pollut., 113(1-4), 337356. doi:http://dx.doi.org/10.1023/A:1005014532330.

Kilroy, G., Coxon, C., Allott, N., \& and Rybaczuk, K. (2001). The contribution of groundwater phosphorus to surface water eutrophication in Ireland. In C. Griebler, D. L. Danielopol, J. Gibert, H. P. Nachtnebel, and J. Notenboom (Eds.), Groundwater Ecology - A Tool for Management of Water Resources (pp. 343-349). Luxembourg: Office for Official Publications of the European Communities.

Lindsey, C. M., \& Bauer, F. C. (1929). Test your soil for acidity. Agriculture Experiment Station Circulation 346. University of Illinois.

Mallarino, A. P., \& Wittry, D. J. (2004). Efficacy of grid and zone soil sampling approaches for site-specific assessment of phosphorus, potassium, pH, and organic matter. Precis. Agric., $5,131-144$.

Mallarino, A., \& Wittry, D. J. (1997). Use of DGPS, yield monitors, soil testing and variable rate technology to improve phosphorus and potassium management. Proceedings of the Integrated Crop Management Conference (pp. 267-275). Ames, Iowa: Iowa State University Extension.

McBratney, A. B., \& Pringle, M. J. (1999). Estimating average and proportional variograms of soil properties and their potential use in precision agriculture. Precis. Agric., 1(2), 125-152. doi:http://dx.doi.org/10.1023/A:1009995404447.

McCobb, T. D., LeBlanc, D. R., Walter, D. A., Hess, K. M., Kent, D. B., \& Smith, R. L. (2003). Phosphorus in a ground-water contaminant plume discharging to Ashumet Pond, Cape Cod, Massachusetts. U.S. Geological Survey Water Resources Investigations Report 02-4306.

Miller, J. J., Chanasyk, D. S., Curtis, T. W., \& Olson, B. M. (2011). Phosphorus and nitrogen in runoff after phosphorus- or nitrogenbased manure applications. J. Environ. Qual., 40(3), 949-958. doi:http://dx.doi.org/10.2134/jeq2010.0279.

Mittelstet, A. R., Heeren, D. M., Fox, G. A., Storm, D. E., White, M. J., \& Miller, R. B. (2011). Comparison of subsurface and surface runoff phosphorus transport rates in alluvial floodplains. Agricult. Ecosys. Environ., 141(3-4), 417-425. doi:http://dx.doi.org/10.1016/j.agee.2011.04.006.

NRCS [Natural Resource Conservation Service]. (2013). Nutrient Management Code 590. Natural Resource Conservation Service, Conservation Practice Standard. Retrieved from www.nrcs.usda. gov/Internet/FSE_DOCUMENTS/stelprdb1081578.docx.

Olson, B. M., McKenzie, R. H., Larney, F. J., \& Bremer, E. (2010). Nitrogen- and phosphorus-based applications of cattle manure and compost for irrigated cereal silage. Can. J. Soil Sci., 90(4), 619-635. doi:http://dx.doi.org/10.4141/cjss10026.

Polyakov, V., Fares, A., \& Ryder, M. H. (2005). Precision riparian buffers for control of nonpoint source pollutant loading into surface water: A review. Environmen. Rev., 13(3), 129-144. doi:http://dx.doi.org/10.1139/a05-010.

Pote, D. H., Daniel, T. C., Nichols, D. J., Sharpley, A. N., Moore, J. P., Miller, D. M., \& Edwards, D. R. (1999). Relationship between phosphorus levels in three Ultisols and phosphorus concentrations in runoff. J. Environ. Qual., 28(1), 170-175. doi:http://dx.doi.org/10.2134/jeq1999.00472425002800010020x. 
Pote, D. H., Daniel, T. C., Sharpley, A. N., Moore, P. A., Edwards, D. R., \& Nichols, D. J. (1996). Relating extractable soil phosphorus to phosphorus losses in runoff. Soil Sci. Soc. Am. J., 60(3), 855-859. doi:http://dx.doi.org/10.2136/sssaj1996. $03615995006000030025 \mathrm{x}$.

Robert, P. C. (2002). Precision agriculture: A challenge for crop nutrition management. Plant Soil, 247(1), 143-149. doi:http://dx.doi.org/10.1023/A:1021171514148.

Sharpley, A. N., McDowell, R. W., Weld, J. L., \& Kleinman, P. J. (2001). Assessing site vulnerability to phosphorus loss in an agricultural watershed. J. Environ. Qual., 30(6), 2026-2036. doi:http://dx.doi.org/10.2134/jeq2001.2026.

Sharpley, A. N., Weld, J. L., Beegle, D. B., Kleinman, P. J., Gburek, W. J., Moore, J. P., \& Mullins, G. (2003). Development of phosphorus indices for nutrient management planning strategies in the United States. J. Soil Water Conserv., 58(3), 137-152.

Sims, J. T., Edwards, A. C., Schoumans, O. F., \& Simard, R. R. (2000). Integrating soil phosphorus testing into environmentally based agricultural management practices. J. Environ. Qual., 29(1), 60-71.

doi:http://dx.doi.org/10.2134/jeq2000.00472425002900010008x

Soil and Plant Analysis Council. (2000). Chapter 6: Phosphorus. In J. B. Jones (Ed.), Soil Analysis Handbook of Reference Methods (pp. 69-92). Boca Raton, Fla.: CRC Press.
Thom, W. O., Schwab, G. J., Murdock, L. W., \& Silora, F. J. (2003). AGR-16 Taking soil test samples. Lexington, Ky.: University of Kentucky Cooperative Extensive Service.

Thomas, G. W., Haszler, G. R., \& Crutchfield, J. D. (1992). Nitratenitrogen and phosphate-phosphorus in seven Kentucky streams draining small agricultural watersheds: Eighteen years later. $J$. Environ. Qual., 21(1), 147-150. doi:http://dx.doi.org/10.2134/ jeq1992.00472425002100010023x.

UK-CES. (2012). AGR-1 Lime and nutrient recommendations. Lexington, Ky.: University of Kentucky Cooperative Extension Service.

Veni, G. (2002). Revising the karst map of the United States. $J$. Cave Karst Stud., 64(1), 45-50.

White, W. B., Watson, R. A., Pohl, R. R., \& Brucker, R. (1970). The Central Kentucky Karst. Geogr Rev, 60(1), 88-115. doi:http://dx.doi.org/10.2307/213346.

Wollenhaupt, N. C., Wolkowski, R. P., \& Clayton, M. K. (1994). Mapping soil test phosphorus and potassium for variable-rate fertilizer application. J. Prod. Agric., 7(4), 441-448. doi:http://dx.doi.org/10.2134/jpa1994.0441.

Zhou, W., \& Beck, B. F. (2008). Management and mitigation of sinkholes on karst lands: An overview of practical applications. Environ. Geol., 55(4), 837-851. doi:http://dx.doi.org/10.1007/s00254-007-1035-9. 